\title{
Source Apportionment of Heavy Metal Contaminated Soil Around a Urea Fertilizer Factory and Probabilistic Risk Assessment of Human Health
}

\section{Shirin Akter}

AECD: Atomic Energy Centre

Mohammad Obidur Rahman

Jahangirnagar University

Mehedi Hasan

Atomic Energy Centre

Saiful Islam Tushar

University of Dhaka: Dhaka University

Mottalib Hossain Sarkar

Atomic Energy Centre

Khan Mohammad Mamun

Atomic Energy Centre

Mohammad Jamiul Kabir

Atomic Energy Centre

Mohammad Safiur Rahman

Atomic Energy Centre

Mohammad Joynal Abedin

Atomic Energy Centre

Bilkis Ara Begum

Atomic Energy Centre

Yeasmin Nahar Jolly ( $\nabla_{\text {jolly_tipu@yahoo.com ) }}$

AECD: Atomic Energy Centre

\section{Research Article}

Keywords: Health Risk Index (HRI), Metal Pollution Index (MPI), X-ray Fluorescence (XRF) Spectroscopy, Carcinogenic Risk, Ecological Risk (RI)

Posted Date: June 14th, 2021 
DOI: https://doi.org/10.21203/rs.3.rs-418592/v1

License: (c) (1) This work is licensed under a Creative Commons Attribution 4.0 International License. Read Full License 


\title{
Source apportionmentof heavy metal contaminated soil around a Urea fertilizer factory andprobabilistic risk assessmentof human health
}

\author{
Shirin Akter ${ }^{1}$, MohammadObidur Rahman ${ }^{2}$, Mehedi Hasan ${ }^{1}$, Saiful IslamTushar ${ }^{4}$, Mottalib Hossain Sarkar ${ }^{1}$ \\ KhanMohammad Mamun ${ }^{1}$, Mohammad Jamiul Kabir ${ }^{1}$, Mohammad Safiur Rahman ${ }^{1}$, Mohammad JoynalAbedin ${ }^{3}$, \\ BilkisAraBegum ${ }^{1}$ and YeasminNaharJolly ${ }^{1 *}$ \\ ${ }^{1}$ Atmospheric and Environmental Laboratory, Chemistry Division, Atomic Energy Centre Dhaka, Bangladesh \\ ${ }^{2}$ Department of Physics,Jahangirnagar University, Bangladesh \\ ${ }^{3}$ Accelerator Facilities Division, Atomic Energy Centre Dhaka, Bangladesh. \\ ${ }^{4}$ Department of Chemistry, University of Dhaka,Bangladesh.
}

(1)

\section{Abstract}

The mean concentrations of heavy metals viz: $\mathrm{K}, \mathrm{Ca}, \mathrm{Mg}, \mathrm{Ti}, \mathrm{Fe}, \mathrm{Co}, \mathrm{Cu}, \mathrm{As}, \mathrm{Zn}, \mathrm{Rb}, \mathrm{Sr}, \mathrm{Zr}, \mathrm{Pb}$ and $\mathrm{Th}$ were measured in soil samples using Energy Dispersive X-ray Fluorescence (EDXRF) technique and sampling sites as a whole were found highly contaminated by $\mathrm{Zn}$, considerably contaminated by $\mathrm{Mg}$ and $\mathrm{Pb}$, while moderately contaminated by $\mathrm{Fe}, \mathrm{Co}, \mathrm{Cu}, \mathrm{Rb}, \mathrm{Sr}, \mathrm{As}, \mathrm{Rb}, \mathrm{Y}$, Th. The sampling sites are moderate to strongly polluted by heavy metals according to Enrichment factors value, whereas, Pollution Load Index values for 95\% of the sample sites were $\geq 1.5$, indicating deterioration of soil quality. Potential Ecological risk (RI) value followed the increasing sequence of $\mathrm{Pb}>\mathrm{As}>\mathrm{Co}>\mathrm{Zn}>\mathrm{Cu}$. Non-carcinogenic exposure found higher in children compared to adults, however carcinogenic risk assessment revealed that both groups (adult and children) lied within Grade II category (10 $50^{-5}$ to $10^{-6}$ ) and considered to be at no risk.

Keywords: Health Risk Index (HRI), Metal Pollution Index (MPI), X-ray Fluorescence (XRF) Spectroscopy, Carcinogenic Risk, Ecological Risk (RI).

*Corresponding Author: Dr. YeasminNahar Jolly

E mail: jolly_tipu@yahoo.com 


\section{Introduction}

36 Fertilizers are applied to increase and enhance the crop yield and ensure healthy produce by appropriate balance of

37 nutrient to the soil. Exact balance of fertilizer helps in soil quality depletion and hence helps in proper growth of plant. Basically fertilizers are chemical substances that promotes the crop productivity by supplying nitrogen, potassium and phosphorous and enhance the water retention capacity of the soil, increase soil fertility as well.Among different types of chemical fertilizers urea is the most important nitrogenous fertilizer to improve the quality of soil providing nitrogen to increase the yield of crops.Soil is a complex matrix that can absorb pollutants like metals (Hamaker et al.1972 and Thompson et al. 1972), which becomes common across the globe due to increase in geologic and anthropogenic activities. Emission and waste disposal from rapidly expanding industrial areas, coal combustion, use of chemical fertilizer, waste water irrigation, domestic wastes are known to be responsible for the release of heavy metals into the soil, leaving behind lasting effects for years (Fusion et al. 1999), since they are environmentally stable, non-biodegradable, and tend to cause accumulation in soils. In addition to anthropogenic sources, toxic pollutants may be derived from other sources such as the weathering of naturally high background rocks and metal deposits (Senesi et al. 1999).When the surface soils are contaminated, they consequently serve as a transmitter of pollutants to surface water, groundwater, atmosphere, and food. Excessive accumulation of heavy metals in soil may not only result in soil pollution or contamination, but can also lead to elevate heavy metal (HM) uptake by plants, and thus affect food quality and safety (Muchuweti et al. 2006).

52 Therefore heavy metal accumulation in soil is of increasing concern as it ultimately becomes the potential source of 53 human health risks (Singh et al. 2010). This problem has been focused by many researchers and widely reported 54 (Eriyamremuet al.2005; Muchuweti et al. 2006; Satarug et al. 2000).However, heavy metal contaminated soil can 55 affect human health in two ways viz: via food chain or may directly from soil dust. Direct ingestion of particles $56\left(\mathrm{ADD}_{\text {ing }}\right)$; inhalation of the suspended particles through mouth and nose $\left(\mathrm{ADD}_{\mathrm{inh}}\right)$; dermal absorption of trace 57 elements in particles adhered to exposed skin $\left(\mathrm{ADD}_{\text {dermal }}\right)$ (Ihediohaet al.2017) are the three major direct human 58 exposure pathway.

59 The Jamuna Fertilizer Company Ltd. Jamalpur of Bangladesh produces Urea fertilizer, contributing significantly to meet the demand for urea fertilizer of the country from years. The main raw materials used are the natural gas,

61 differentchemicals like $\mathrm{Fe}_{2} \mathrm{O}_{3}, \mathrm{Fe}_{3} \mathrm{O}_{4}, \mathrm{Al}_{2} \mathrm{O}_{3}, \mathrm{~K}_{2} \mathrm{O}, \mathrm{CaO}$, and $\mathrm{SiO}_{2}$ etc. However the factory dischargesthe 
62 liquidwastes to the nearby lands which finally go to the Jamuna River and to the adjacent agricultural lands. In this 63 way, the soil gets contaminated and causes toxicity to the public thereafter when the land isused for agricultural 64 cultivation. A vast investigation therefore needed to understand the present heavy metal status of that area, their 65 potential sources as well as impact on human health.The present study was sketched to determine qualitatively and 66 quantitatively the concentrations of heavy metals ( $\mathrm{Mg}, \mathrm{K}, \mathrm{Ca}, \mathrm{Ti}, \mathrm{Fe}, \mathrm{Co}, \mathrm{Cu}, \mathrm{Zn}, \mathrm{As}, \mathrm{Rb}, \mathrm{Sr}, \mathrm{Zr}, \mathrm{Pb}$ and $\mathrm{Th}$ )in the

67 near-surface $(\sim 0-20 \mathrm{~cm})$ soils around theJamuna Fertilizer Company Ltd., area using Energy Dispersive X-ray 68 fluorescence spectrometry (EDXRF) and to assess the extent of pollution by calculating some contamination indices and ecological risk assessment . To find outthe possible sources statistical analysis like Pearson correlation,

70 Principal Component Analysis (PCA) has been done and the impact on direct human exposure via inhalation,

71 ingestion and dermal contact of soil dust evaluated as well.

\section{Materials and methods}

\section{Study Area}

74 The North-East side of 'The Jamuna Fertilizer Co. Ltd.Jamalpur of Bangladesh (geographical coordinates are at $24^{\circ}$ 75 59' 0" North, 90 6' 0" East), a residential cum agricultural field area,was selected as the study area and soil samples 76 were collected randomly from twenty different points around the Fertilizer factory. There are cultivation lands near 77 the factory site which received huge amount of solid and liquid waste, in addition to the discharge from fertilizer 78 factory; the study area is getting contaminated by a nearby car workshop, from where wastes are frequently 79 dumped.The site map of sampling area is shown in Fig. 1.

\section{Sample collectionand preparation}

81 A total of 20 soilsamples were collectedfrom different places of the sampling siteusing stainless-steel specula at 82 regular intervals of $2 \mathrm{~m}$ at specific transects and labeled as soil-1 to soil-20. The soil samples after collection were 83 sieved with a stainless steel sieve to remove dirt and plant materials. Samples were then separately taken into 84 porcelain dishes and placed in an oven at around $70^{\circ} \mathrm{C}$ for complete drying. Each driedsample wasgrounded to fine 85 powder using a mortar and pestle and preserved in a distinctly marked plastic vial inside a desiccator. The 86 homogeneous powder was used to prepare pellet $(7 \mathrm{~mm}$ dia. and $1 \mathrm{~mm}$ thick) using 10 ton pressure by a pellet maker 87 (Specac, UK) for elemental analysis by EDXRF.

\section{Sample irradiation and method validation}

89 The sample irradiation was performed using Energy Dispersive X-ray Fluorescence (EDXRF) Spectroscopy System. 
90 The entire process is done following (Shirin et al. 2019).The X-Ray beam of $22.4 \mathrm{keV}$ from ${ }^{109} \mathrm{Cd}$ point source hits

91 the target sample to produce the characteristic X-rays, the [Si (Li)] detector (Canberra) having the resolution of

$92 \quad 175 \mathrm{eV}$ at $5.9 \mathrm{keVdetects}$ the characteristic X-rays, which are ultimately converted into voltage pulses and amplified

93 by the spectroscopy amplifier and then finallyprocessed in MCA having $16 \mathrm{~K}^{+}$channel.The irradiation and spectrum

94 data acquisition are operated and controlled by a software package provided with the system (AXIL). The standard

95 materials were also irradiated under similar experimental conditions for construction of the calibration curves for

96 quantitative elemental determination in the respective samples. The commercial software AXIL has been applied for

97 the qualitative and quantitative elemental determination.

98 In EDXRF technique, a simple comparison is appliedfor elemental concentration measurement (Islam et al.2007 and

99 Jolly et al.2007 and Jolly et al.2012).In the present study, three pellets from commercially available soil standard

100 (Soil-7 /IAEA)were used to construct a calibration curve, by plotting the sensitivities of the elements as a function of

101 their atomic number. The calibration curve was validated and checked through analysis of standard reference

102 materials "Montana-1/2710a". The results obtained for elements of interest and certified values for corresponding

103 elements are in good agreement as they are found to vary within the acceptable range of error $( \pm 10 \%)$. The entire

104 process was describing elsewhere (Jolly et al. 2013).

105 Assessment of metal contamination

106 Geo-accumulation index (Igeo)

107 Geo-accumulation index (Igeo) is measured using the following equation (Abrahimet al. 2008 and Parker et al.

108 2008):

$$
\text { Igeo }=\log 2 \frac{\mathrm{Cx}}{1.5 \times \mathrm{Bx}}
$$

110 Where, $\mathrm{C}_{\mathrm{x}}$ refers the measured concentration of the metal $\mathrm{x}, \mathrm{B}_{\mathrm{x}}$ is the geochemical background concentration of metal $111 \mathrm{x}$ and 1.5 is the background matrix correction factor due to lithospheric effects. The geo-accumulation index consists

112 of seven grades or classes (Bhuiyanet al. 2010; jolly et al. 2018). Class 0 (practically uncontaminated): Igeo $\leq 0$;

113 Class 1 (uncontaminated to moderately contaminated): $0<$ Igeo $<1$; Class 2 (moderately contaminated): $1<$ Igeo $<2$;

114 Class 3(moderately to heavily contaminated): 2 <Igeo< 3; Class 4 (heavily contaminated): 3 <Igeo< 4; Class 5

115 (heavily to extremely contaminated): $4<$ Igeo $<$ 5; Class 6 (extremely contaminated): 5 <Igeo. Class 6 is an open

116 class and comprises all values of the index higher than Class 5. The elemental concentrations in Class 6 may be

117 hundredfold greater than the geochemical background value (Bhuiyan et al. 2010). 
To estimate the anthropogenic heavy metal impact on soil, a normalized enrichment factor (EF) for metal concentrations above uncontaminated background levels (Hornung et al. 1989;Dickinson et al. 1996; Abrahim and Parker 2008; Bhuiyan et al. 2010) is necessary. Thus EF can be calculated by using the following equation:

$$
E F=\frac{(\text { Metal } / \mathrm{Fe}) \text { Sample }}{(\text { Metal } / \mathrm{Fe}) \text { Background }}
$$

Following (Tamim et al. 2016), iron (Fe) was used as the reference element for geochemical normalization in the

124 present study. The EF values close to unity indicate crusted origin (comparable to those of UCC) of the metals, those

125 less than 1.0 suggest a possible mobilization or depletion of metals (Zsefer et al., 1996), whereas EF>1.0 indicates that the element is of anthropogenic origin. $\mathrm{EF}$ values $\mathrm{EF}<2,2<\mathrm{EF}<5,5<\mathrm{EF}<20,20<\mathrm{EF}<40$, and $\mathrm{EF}<40$ are the

127 indication of minimal, moderate, significant, very high and extremely high enrichment respectively.

\section{Contamination Factor $(\mathbf{C F})$}

129 The contamination status of the soil can be determined by calculating contamination factor (CF) following 130 (Thomilson et al. 1980) as below:

$$
C F=\frac{\text { Cmetal }}{\text { C background }}
$$

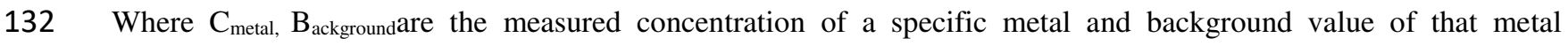
respectively. World surface rock average proposed by(MartinandMeybeck 1979) is considered as background

134 concentration for the present study.The contamination levels were classified based on their intensities on a scale 135 ranging from 1 to 6 as shown in Table 1 . The highest number indicates that the metal concentration is 100 times greater than what would be expected in the crust.

\section{Pollution load index (PLI)}

138 Pollution load index (PLI) is calculated from the Contamination Factors (CF) of the specific heavy metals for a 139 specific sampling site, which can be defined by following(Hakanson Let al. 1980) and categorized by following 140 (Zhao et al. 2012) as low (CF<1), moderate (CF: 1-3), considerable (CF: 3-6) and high (CF>6). Following 141 Tomlinson et al. (1980), PLI can be calculated by the equation bellow:

$$
\mathrm{PLI}=\left(\mathrm{CF}_{1} \times \mathrm{CF}_{2} \times \mathrm{CF}_{3} \times------------\times \mathrm{CFx}\right)^{1 / \mathrm{x}}
$$


143 Where, $\mathrm{CF}_{1}$ to $\mathrm{CFx}$ represents the contamination factors for the specific toxic metals and $\mathrm{x}$ is the total number of contamination factors considered. PLI=1 indicates the presence of only baseline levels of pollutants and values

145 above 1 indicate progressive deterioration of the site quality(Mohiuddin et al. 2010).

\section{Degree of contamination $(\mathbf{C d})$}

147 Degree of contamination (Cd) is usually calculated to determine the contamination status of the sediment/soil in and 148 defined as the sum of all contamination factors as:

$$
\mathrm{Cd}=\sum \mathrm{CF}
$$

Where, $\mathrm{Cd}<8=$ Low, $8 \leq \mathrm{Cd}<16=$ moderate, $16 \leq \mathrm{Cd}<32=$ considerable and $32 \leq \mathrm{Cd}=$ very high degree of contamination respectively.

\section{Nemerow Comprehensive Index $\left(\mathbf{P}_{\mathrm{N}}\right)$}

153 Nemerow index method is widely used to assess the integrated and comprehensive pollution status of the heavy 154 metals and metalloids in soil(Chen et al. 2010). The single factor index (Pi) method was applied to measure the 155 pollution degree of a single pollutant in the soil samples. This method could highlight the most important pollutant which influences the most pollution at an individual site easily and clearly. On the other hand the Nemerow

157 pollution index (Pn) was used to evaluate the comprehensive pollution status of soils with all the heavy metals of 158 concern (Chen, 2010). Since different heavy metals might have impacts on one site, this method could provide a 159 reasonable interpretation of the heavy metal pollution at each site as a whole.

160 The expression of $\mathrm{P}_{\mathrm{i}}$ is as follow:

$$
P_{i}=\frac{\mathrm{C}_{\mathrm{i}}}{\mathrm{S}_{\mathrm{i}}}
$$

where $\mathrm{Pi}$ is the single factor index of individual metal, Ci represents the actual measured concentration of metals in soil and Si represents the geochemical background content(Kabata-Pendias2011).Pi $\mathrm{i}_{\text {avg }}$ indicates the mean value of Pi

164 whereas $\mathrm{Pi}_{\max }$ represents the maximum value in an individual sampling site. To evaluate the integrated 165 environmental quality ofthe soil of any particular area of interest it is only necessary to calculate the Pn value and then compare it with the corresponding classification standard (Table 1)(Chen et al. 2008).

167 However $\mathrm{P}_{\mathrm{N}}$ is calculated by following equation:

$$
P_{N}=\frac{\sqrt{(\mathrm{Pi})_{\text {mean }}^{2}}+(\mathrm{Pi})_{\text {max }}^{2}}{2}
$$


$\left(\mathrm{P}_{\mathrm{i}}\right)_{\max }$ and $\left(\mathrm{P}^{\mathrm{i}}\right)_{\text {mean }}$ refer to maximum and average values of $\mathrm{P}_{\mathrm{i}}$, among the target elements respectively (Li et al.

171 limit, slight pollution, moderate pollution and heavy pollution respectively by individual elements.

\section{Potential Ecological Risk Index}

173 (Hakanson et al.1980) proposed potential ecological risk of individual factors $\left(\mathrm{E}_{\mathrm{r}}^{\mathrm{i}}\right)$ and the potential ecological risk

174 index (RI)for the evaluation of the potential ecological risk of pollutants in soils by the equation:

$$
\begin{aligned}
& E_{r}^{i}=T_{r \times}^{i} \frac{C^{i}}{C_{n}^{i}} \\
& R I=\sum_{i}^{m} E_{r}^{i}
\end{aligned}
$$

Where $E_{r}^{i}$ the ecological risk of a single factor is, $C^{i}$ is the measured concentration of the metal in soil $C_{n}^{i}$ is the geochemical background in the soil (Chen et al. 1992), $\mathrm{m}$ is the analyzed metal concentration, $T_{r}^{i}$ is the toxicity response coefficient of heavy metals which are 5, 5, 1, 5, 10 for $\mathrm{Co}, \mathrm{Cu}, \mathrm{Zn}, \mathrm{Pb}$ and Asrespectively used in the present study. $E_{r}^{i}$ is categorized as $<40$ low risk, 40-80 moderate risk, 80-160 considerable risk, 160-320 high risk, $\geq 320$ very high risk and RI value $<100,100-200,200-400, \geq 400$ referred as low, moderate, considerable, high risk respectively.

\section{Human health risk assessment}

Hazard Quotient (HQ)

185 The exposure risks of soil metals posed to the public are calculatedfollowing the United States of Environmental 186 Protection Agency suggestive formula for health risk assessment (US Environmental Protection Agency 1989; US Environmental Protection Agency 2001).Ingestion of particles ( $\left.\mathrm{ADD}_{\text {ing }}\right)$; inhalation $\left(\mathrm{ADD}_{\mathrm{inh}}\right)$; dermal absorption of 188 trace elements via skin (Thediohaet al.2017)are the three major direct pathway for human exposure. Presently $\mathrm{Cu}$, $\mathrm{Zn}$, Asand Pbweretaken as the subject for calculating the health risk assessment via soil dust, where As and Pbposed a carcinogenic risk, and other are non-carcinogenic. Populationgroup: adults and children are considered and the

191 doses calculated for each element and exposure pathway are subsequently divided by the toxicity threshold value, 192 which is referred to as the reference dose (RfD), of a specific element to yield a non-carcinogenic Hazard quotient 193 (HQ), whereas the Hazard index (HI) is the total non-carcinogenic risk of all exposure pathways to a variety of 194 pollutants (USEPA 1989; Li et al. 2014). For carcinogens, the dose is multiplied by the corresponding slope factor 
195

196

197

(SF) to produce a level of carcinogenic risk (Ferreira-Baptista2005)which is regarded as the probability of an individual developing any type of cancer in their whole life time due to exposure to carcinogenic hazards .

Hazard Quotient (HQ) implies the Non-carcinogenic hazards, expressed as the probability of an individual suffering an adverse effect. It is defined as the quotient of ADI or dose, divided by the toxicity threshold value, which is referred to as the chronic reference dose (RfD) in $\mathrm{mg} / \mathrm{kg}$-day of a specific heavy metal.It is an exceedance of ingested pollutant when ingested exposure dose is compared with the oral reference dose and when the value of HQ is less than 1, then the exposed population (consumers) is safe but HQ equal to or higher than 1, means the human health is not safe, therefore potential health risk occurred, and related interventions for protective measures are required. However, HQ parameter does not estimate the risks; it only indicates a risk level associated with pollutants exposure. The non-carcinogenic risk was estimated using HQ calculated for heavy metals by using the following equation:

$$
\text { Hazard Quotient }(\mathrm{HQ})=\mathrm{HQ}=\frac{\mathrm{ADD}}{\mathrm{RfD}}
$$

Where, ADD is the Dose due to the exposure of heavy metals and RfD is the oral reference dose. The oral reference dose is the dose of a substance that can be taken in daily without identifiable risk for lifetime exposure or the daily oral exposure for the human population, which does not cause deleterious effects during a life-time.

Ingestion of Heavy Metals through Soil was calculated thus;

$$
\mathrm{ADD}_{\text {ing }}=C \times \frac{\operatorname{IngRXEFXED}}{B W X A T} \times 10^{-6}
$$

Where, $\mathrm{ADD}_{\text {ing }}$ is the average daily intake of heavy metals, ingested from the soil, in $\mathrm{mg} / \mathrm{kg}$-day, $\mathrm{C}$ indicates the concentration of heavy metal in $\mathrm{mg} / \mathrm{kg}$ for soil. IngRis the soil ingestion rate in $\mathrm{mg} / \mathrm{day}$; $\mathrm{EF}$, the exposure frequency in days/year; ED the exposure duration in years; BW, the body weight of the exposed individual in $\mathrm{kg}$; and AT, the time period over which the dose is averaged in days. Also CF is the conversion factor inkg/mg.

Inhalation of Heavy Metals via Soil Particulates was calculated thus;

$$
\mathrm{ADD}_{\text {inh }}=\mathrm{C} \times \frac{\operatorname{IngRXEFXED}}{P E F \times B W X A T}
$$

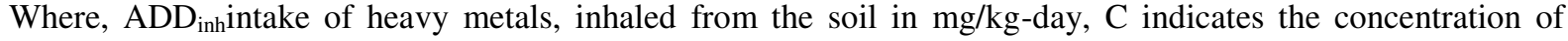
heavy metal in soil in $\mathrm{mg} / \mathrm{kg}$, and IngRand PEF are the soil inhalation rate in mg.day ${ }^{-1}$ and the particulate emission factor in $\mathrm{m}^{3} / \mathrm{kg}$, respectively. EF, ED, BW, and AT are as defined earlier in Equation (2) above. 
Dermal Contact with Soil is calculated thus;

$$
\mathrm{ADD}_{\text {dermal }}=\mathrm{C} \times \frac{S A X S L X A B S \times E F \times E D}{B W X A T} \times 10^{-6}
$$

224 Where, $\mathrm{ADD}_{\text {dermal }}$ is the exposure dose via dermal contact in $\mathrm{mg} / \mathrm{kg} / \mathrm{day}$. C represents the concentration of heavy

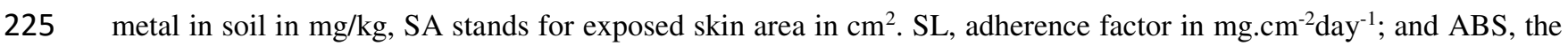
226 fraction of the applied dose absorbed across the skin, unitless. EF, ED, BW, CF, and AT are as defined earlier in 227 Equation (2). Table 2 shows the exposure parameters, used for health risk assessment of standard residential 228 exposure scenario through different exposure pathways.

229 For $\mathrm{n}$ number of heavy metals, the non-carcinogenic effect on population is as a result of the sum of all HQ's due to 230 individual heavy metals, which is referred to as another term called Hazard Index (HI), as described by (USEPA 231 1989). Equation (5) shows the mathematical representation of this parameter

$$
\mathrm{HI}=\sum \mathrm{HQ}_{\mathrm{i}}=\mathrm{HQ}_{\text {ing }}+\mathrm{HQ}_{\text {inh }}+\mathrm{HQ}_{\text {der. }}
$$

For carcinogens, the risks are estimated as the incremental probability of an individual developing cancer over a lifetime as a result of exposure to potential carcinogens. The equation to calculate excess lifetime cancer risk is:

$$
\text { Cancer risk }=\mathrm{ADD} \times \mathrm{SF}
$$

Final calculation for the total excess lifetime cancer risk for an individual from the average contribution of the individual heavy metals for all pathways are done using the following equation:

$$
\mathrm{Risk}_{\text {Total }}=\text { Risk }_{\text {ingestion }}+\text { Risk }_{\text {inhalation }}+\text { Risk }_{\text {dermal }}
$$

239 For the Risk factor calculation the dose is multiplied by the corresponding slope factor to produce a level of 240 carcinogenic risk. If the risk is $<10^{-4}$ then it is said to be the acceptable carcinogenic risk value range $(\mathrm{Gu}, \mathrm{Y} \mathrm{G}, \mathrm{Gao}$,

241 Y P,\& Lin, Q 2016).

\section{Result and Discussion}

243 Heavy metal abundance in and around fertilizer factory soil

244 The results of heavy metal concentrations for each sampling site in soil presented in Table 3 ranged over the following intervals; Mg: 7812-24257 (mean14712), K: 5631-15115(mean 11828), Ca: 4906-12408(mean 8607), Ti:

246 2874-5886(mean 4378), Fe: 20470-62465(mean 47358), Co: 3.25-22.90 (mean 10.93), Cu: 10.22-27.54 (mean

247 17.04), Zn: 61.55-282.09 (mean 151.57). As: 5.63-13.08 (mean 8.65), Rb: 114.91-258.32 (mean 191.08), Sr: 132.73-

248287.46 (mean 191.42), Zr: 206.62-337.14 (mean 263.64), Pb: 61.77-132.24 (mean 88.69), and Th: 9.46-25.43 (mean

249 17.55) $\mathrm{mg} \mathrm{kg}^{-1}$ respectively. The mean concentrations of $\mathrm{Mg}, \mathrm{Fe}, \mathrm{Cu}, \mathrm{Zn}, \mathrm{Rb}, \mathrm{Sr}, \mathrm{Th}, \mathrm{As}, \mathrm{Co}$ and $\mathrm{Pb}$ were higher and 
$\mathrm{K}, \mathrm{Ca}$, Ti and $\mathrm{Zr}$ were lower compared to world average values as reported by Taylor and Francis group LLC, 2011.Heavy metals occur in many fertilizers and pesticides (Ahmed and Goni 2010, Aucejo et al. 1997 and

252 Facchinelli et al.2001) suggested that wastewater is the main source for metal in agricultural soil. The mean concentrations of $\mathrm{Znand} \mathrm{Pb}$ in agricultural soil in the present investigation were found higher than reported by (Ratul et al. 2018). The mean concentrations of $\mathrm{Co}$ and As were found lower but $\mathrm{Cu}$ and $\mathrm{Zn}$ concentrations were higher than reported by(Kkodomet al. 2012). The mean concentrations of $\mathrm{Cu}$, As and $\mathrm{Pb}$ in some sites were higher than the Dutch soil quality standard (VROM 2000)except Zn, indicating metals in soil might pose adverse effect on humans,

257 plants and animals.

\section{Possible source identification}

\section{Pearson correlation matrix analysis}

The Pearson correlation matrix in different elements in order to identify the correlation among the heavy metals in the soil sample are given in Table 4.The strength that associated in between different elements, indicating by $\mathrm{p}$ value refers 0.01 and 0.05 as strong and significant correlations respectively. Present study reveals that $\mathrm{Mg}, \mathrm{Al}, \mathrm{Si}, \mathrm{Ca}, \mathrm{Zr}$ possess positive correlations with each other and $\mathrm{Al} \& \mathrm{~K}$ possess significant correlation with $\mathrm{Fe}, \mathrm{Ti}, \mathrm{Rb}, \mathrm{Y}, \mathrm{Pb} \& \mathrm{Th}$. All the alkali and alkali earth metals correlate positively with $\mathrm{Si}$. Al correlates with $\mathrm{Fe}$ in weathered materials and can be an indicator of mafic rocks. $\mathrm{Cu}, \mathrm{Zn}, \mathrm{Pb} \& \mathrm{Th}$ also possess significant correlation with each other. Similarly $\mathrm{Zr}$, Th, Y \&Pbare significantly correlated with each other. In nature, thorium occurs in the +4 oxidation state, together with Yttrium and other heavy metals.Zr and $\mathrm{Y}$ generally considered as immobile elements for mass balance evaluation, are mobile in some cases under extreme climatic conditions. Zr exhibits strong positive correlation with

$269 \mathrm{Si}$ and hence Zircon is a mineral belonging to the group of silicates. $\mathrm{Zr}$ also shows significant correlation with $\mathrm{Ca}$, however traces of $\mathrm{Zr}$ also exist in limestone (Kabata-Pendias1993). It also noted that As possesses very weak or

271 negative correlation with other metals. The strong positive correlation could indicate similar source origin of heavy

272 metal in different soil sample.

273 Principal component analysis

274 The total variance in each factor was calculated as the sum of the squared loadings for the given factor. The scree 275 plot (Fig.2) is used to identify the number of PCs to be retained to understand the underlying element structure.In this study six factors which represents $90 \%$ of the total variance referred as PC1, PC2 PC3, PC4,PC5\& PC6 explain

277 more than $42 \%, 17 \%, 9 \%, 7 \%, 7 \%$ \& $5 \%$ of variance respectively and the Eigen values are 8.117, 3.282, 1.885, 
$1.459,1.359,1.024$ for each component (Fig.3). The first principal component PC1 is highly loaded with Rb, Ti, Fe,

$\mathrm{K}, \mathrm{Al}, \mathrm{Y}, \mathrm{Pb}, \mathrm{Sr}$ and all of these elements are mostly exist in soilgeogenicaly. The second principal component $\mathrm{PC} 2$ is strongly loaded with $\mathrm{Zr}, \mathrm{Ca}, \mathrm{Mg}$ and weakly loaded with $\mathrm{Si}$. The long-established agricultural practice and liming are the sources of $\mathrm{Ca}$; cement factories, fertilizers, and dust can also be sources of $\mathrm{Ca} \& \mathrm{Mg}$. The third principal component $\mathrm{PC} 3$ is strongly loaded with $\mathrm{Cu}, \mathrm{Zn}$, Th and moderately loaded with $\mathrm{Pb}$. In nature, $\mathrm{Pb}$ is originated as progeny of radioactive thorium andvehicle brakes and tire wear as possible sources of $\mathrm{Zn} \& \mathrm{Cu}$. The fourth principal component PC4 is strongly loaded with only $\mathrm{Sr}$ and can be released from industrial waste, disposal of coal ash, and incinerator ash (Reimann and de Caritat1998). The fifth principal component PC5 is strongly loaded with P and moderately loaded with $\mathrm{Si}$, complies the major anthropogenic sources of phosphate containing fertilizers. The sixth principal component PC6 is strongly loaded with As.PCA correlation circle for the studied elements based on Pearson correlation matrix is shown in Fig.4.

\section{Assessment of pollution status}

Geo-accumulation Index (Igeo) and Enrichment factor (EF)

The Enrichment Factor $(\mathrm{EF})$ and Geo-accumulation Index $\left(\mathrm{I}_{\text {geo }}\right)$ are indicators used to assess the presence and intensity of anthropogenic contaminant deposition on surface soil. The calculated mean geo-accumulation index $I_{\text {geo }}$ (Mulleret al.1979)value ofJamuna fertilizer factory area soils at different sampling points (Fig.5) for the elements $\mathrm{Mg}, \mathrm{K}, \mathrm{Ca}, \mathrm{Ti}, \mathrm{Fe}, \mathrm{Co}, \mathrm{Cu}$ fall in Class 0 (practically uncontaminated): $\mathrm{I}_{\mathrm{geo}} \leq 0$ and for the elements $\mathrm{Zn}, \mathrm{As}$, $\mathrm{Rb}, \mathrm{Sr}, \mathrm{Y}, \mathrm{PbTh}$ in Class 1 (uncontaminated to moderately contaminated): $0<\mathrm{I}_{\text {geo }}<1$. The $\mathrm{I}_{\mathrm{geo}}$ value reveals that the proposed site is moderately contaminated by toxic elements $\mathrm{As}, \mathrm{Pb}, \mathrm{Th}$.Mean $\mathrm{EF}$ values of $\mathrm{K}, \mathrm{Ca}, \mathrm{Ti}, \mathrm{Fe}, \mathrm{Co}, \mathrm{Cu}$, $\mathrm{Zn}, \quad \mathrm{As} \quad \mathrm{Rb}, \mathrm{Sr}, \quad \mathrm{Y}, \mathrm{Zrand}$ Pbfollowed the decreasing order of $\mathrm{Ca}(0.08)<\mathrm{Pb}(0.39)<\mathrm{As}(0.47)<\mathrm{Zn}((0.64)<\mathrm{Y}(0.95)<\mathrm{K}(1.07)<\mathrm{Co}(1.18)<\mathrm{Zr}(1.23)<\mathrm{Rb}(1.32)<\mathrm{Sr}(1.38)<\mathrm{Fe}(1.39)<\mathrm{Cu}(1$.

299 83) $<\mathrm{Ti}(2.18)$ but EF value of Th (Thorium) is not included in this study as of reference values are not available. The EF value of all heavy metals were reported to be $<2$ at all sampling sites (Fig.6) but Ti showed moderate enrichment in the area as it remains between 2 and 5 thus can be severe in the near future so regular monitoring is necessary.

\section{Contamination factor $(\mathbf{C F})$}

303 Sampling point Soil-1is moderately contaminated by $\mathrm{Mg}, \mathrm{Fe}, \mathrm{As}, \mathrm{Zn}$. Cu, Sr Y, Thbut the contamination level of $304 \mathrm{Al}, \mathrm{K}, \mathrm{Ca}, \mathrm{Co}, \mathrm{Ti}$ and Co is very low (Table 5). Similarly, sampling point Soil-2 is moderately contaminated by Mg, $305 \mathrm{Co}, \mathrm{Zn}, \mathrm{As}, \mathrm{Y}, \mathrm{Rb}, \mathrm{PbTh}$ while contamination level is low for $\mathrm{Al}, \mathrm{K}, \mathrm{Ca}, \mathrm{Co}, \mathrm{Ti}, \mathrm{Fe}, \mathrm{Cu}, \mathrm{Sr}$.Soil-3 is considerably 
contaminated by $\mathrm{Rb}$ and Pbbut moderately contaminated by $\mathrm{Mg}, \mathrm{Fe}, \mathrm{Co}, \mathrm{Cu}$, and $\mathrm{Zn}$, As, Sr, Y,Th. Soil-4 is considerably contamination by $\mathrm{Mg}, \mathrm{Zn}$, Pbbut moderately contamination by $\mathrm{Al}, \mathrm{Fe}, \mathrm{Co}, \mathrm{Cu}, \mathrm{As}, \mathrm{Rb}, \mathrm{Sr} \mathrm{Y}, \mathrm{Th}$. Considerable contamination is observed by $\mathrm{Mg}, \mathrm{Zn}$ and moderate contamination by $\mathrm{Fe}, \mathrm{Co}, \mathrm{Cu} \mathrm{As}, \mathrm{Rb}, \mathrm{Sr}, \mathrm{Y}, \mathrm{Pb}, \mathrm{Th}$ in sampling point Soil-5. Moderate contamination is found in sampling point Soil-6, but the considerable contaminants are $\mathrm{Co}, \mathrm{Zn}, \mathrm{Rb}$ and $\mathrm{Pb}$. Similarly Sampling points soil-7,soil-8, soil-9, soil-10,soil-11,soil-12,soil13soil-14,soil-15,soil-16,soil-17, soil-18, and soil-20 are considerably contaminated by $\mathrm{Mg}, \mathrm{Pb}, \mathrm{Zn}, \mathrm{Rb}$, Co; moderatelycontaminated by $\mathrm{Fe}, \mathrm{Co}, \mathrm{Zn}, \mathrm{As}, \mathrm{Rb}, \mathrm{Sr}, \mathrm{Y}, \mathrm{Th}$ and low contamination factor indicative of low contamination by $\mathrm{Al}, \mathrm{K}, \mathrm{Ca}, \mathrm{Ti}, \mathrm{Co}, \mathrm{Cu}$. Finally, sampling point Soil-19 is highly contaminated by only $\mathrm{Zn}$,considerably contaminated $\mathrm{Mg}$, and $\mathrm{Pb}$ and moderately contaminated by $\mathrm{Fe}, \mathrm{Co}, \mathrm{Cu}, \mathrm{Rb}, \mathrm{Sr}, \mathrm{As}, \mathrm{Rb}, \mathrm{Y}$, and $\mathrm{Th}$. It is evident from Table5that the contamination factor for $\mathrm{Pb}, \mathrm{Cu} \mathrm{Mg}, \mathrm{Fe}, \mathrm{Co}, \mathrm{As}, \mathrm{Rb}, \mathrm{Th}, \mathrm{Y}$ and $\mathrm{Zn}$ were higher than other study (Abdullah al zabir et al ,2016), which indicates that $\mathrm{Pb}, \mathrm{Rb}, \mathrm{Mg}$ and $\mathrm{Zn}$ were the major pollutants in those soils.The degree of contamination $(\mathrm{Cd})$ in the studied area at different points reveals that sampling point soil-16 is very highly contaminated ; soil-1, soil-2, soil-3, soil-4, soil-5, soil- 6,soil-7, soil-8, soil-9, soil-10, soil11,soil- 12,soil-13, soil-14, soil-15 soil-17,soil-18, soil-19 and soil-20 - all are at considerable degree of contamination .

\section{Pollution Load Index (PLI)}

The Pollution Load Index (PLI) shown in (Fig.7) suggests thatall the sampling points, except Soil-7, are polluted and deteriorating progressively by different toxic heavy metals with the indication that the middle part of the study area is less polluted than northern and eastern parts of the study area.The highest PLI (2.28) was observed at sampling point (Soil -16) indicates heavily contaminated compared to other sites.

\section{Nemerow Comprehensive index (PN)}

The single factor index of heavy metals of the studied samples showed that the average pollution degree was decreased in the givenorder: $\mathrm{Pb}>\mathrm{Zn}>\mathrm{Ti}>\mathrm{Fe}>\mathrm{Co}>\mathrm{As}>\mathrm{Cu} . \mathrm{Pb}$ had the highest single factor index value and few stations are suffered from severe Zn pollution according to the single factor index(Table 6). The results of the Nemerow pollution index $\left(\mathrm{P}_{\mathrm{N}}\right)$ indicated the sampling site soil-7 and soil 17 had low pollution and fall in the pollution class III, whereas sampling site soil-6, soil-9, soil 16 and soil-19 showed severe heavy metal pollution and fall in the pollution class $\mathrm{V}$ and rest of the sites displayed moderate pollution and fall pollution class IV. Therefore, 
333 in the study area, measures must be taken to avoid the potential trace element contamination of soils to protect environmental health.

\section{Potential Ecological Risk (PERI)}

336 In this study, Potential Ecological Risk (PERI) for the elements $\mathrm{Co}, \mathrm{Cu}, \mathrm{Zn}, \mathrm{Pband}$ As have been calculatedand presented in Table 7. All the sampling site (soil-1 to soil-20) showed high PERI value for the element $\mathrm{Pb}$ and $\mathrm{As}$, while the lowest PERI value varied from element to element and site as well.Thus cobalt (Co) showed lowest value for soil-1, $\mathrm{Cu}$ showed lowest value for soil-3, Soil-4, soil-8, soil-9, soil-10, soil-15, soil-20 and Zn showed lowest value for soil-2, soil-5, soil-6, soil-7, soil-11, soil-12, soil-13, soil-14, soil-16, soil-17, soil-18 and soil-19 respectively.The maximum and minimum value was found 10.133, 3.540, 4.030, 24.488, 19.147 and 1.438, 1.313, $0.879,11.438,8.3243$ for $\mathrm{Co}, \mathrm{Cu}, \mathrm{Zn}, \mathrm{Pb}$ and As respectively. The estimated Potential ecological risk (RI) found highest forPb (16.425) and lowest for $\mathrm{Zn}$ (2.165).

\section{Non -Carcinogenic Hazard quotient (HQ)}

345 Non carcinogenic risk calculationhas been done for the elements $\mathrm{Zn}, \mathrm{Cu}, \mathrm{Pb}$ and $\mathrm{As}$ for both adults and children presented in Table 8, where the HQ value for adults followed the sequence of $\mathrm{Pb}>\mathrm{As}>\mathrm{Cu}>\mathrm{Zn}$ and for children it was $\mathrm{As}>\mathrm{Pb}>\mathrm{Zn}>\mathrm{Cu}$. The exposure rate due to $\mathrm{As}, \mathrm{Pb}, \mathrm{Cu}$ and $\mathrm{Zn}$ is higher in children than the adults. Regardless of age, the HQ and Hazard Index (HI) values of the analyzed metals by different exposure pathways were less than 1, which as a whole indicates that the risk is small and negligible and could cause no obvious health hazards on the surrounding population. From Table8, it may be appraised thatthe direct oral ingestion of soil particles is the highest, followed by dermal absorption of elements in soils adhered to exposed skin, and inhalation of resuspendedsoil particulates by nose or mouth minimization. Again from the calculated result it can beconcluded that direct oral ingestion of soil particles is highest in case of children population. Children exposure risk to arsenic (As)on this note

354 is the highest: HQ reached to 0.1893 , by direct oral ingestion of soil particles. Hazard Index (HI) followed the 355 sequence $\mathrm{as} \mathrm{Pb}>\mathrm{As}>\mathrm{Cu}>\mathrm{Zn}$ and $\mathrm{As}>\mathrm{Pb}>\mathrm{Zn}>\mathrm{Cu}$ for adult and child respectively.

356 Thecarcinogenic risk due to the four heavy metals $\mathrm{Cu}, \mathrm{Zn}$, As and $\mathrm{Pb}$ has been calculated for both the adults and 357 children population (Table 9), from where it is evident that children are more vulnerable than adults and the risk 358 factor of $\mathrm{As}$ is much higher than $\mathrm{Pb}$ in case of children.The total carcinogenic risk factor for children is $7.762 \times 10^{-6}$ which is less than the acceptablecarcinogenic value range $\left(\right.$ Risk $\left.<10^{-4}\right)$ and as the risk value lies within $\left(10^{-6}\right.$ to $\left.10^{-5}\right)$, 
the risk.The total carcinogenic risk factor for adults is $3.326 \times 10^{-6}$ which is within the acceptable range (Risk $<10^{-4}$ ) and did not pose a carcinogenic risk to the population group.

\section{Conclusion}

364 Thestudy presents a detailed investigation of heavy metal pollution inanthropogenically and geogenically impacted soils of a Urea fertilizer factory area.The mean concentrations of metals ( $\mathrm{Fe}, \mathrm{Mg}, \mathrm{K}, \mathrm{Ca}, \mathrm{Ti}, \mathrm{Zr}, \mathrm{Sr}, \mathrm{Rb}, \mathrm{Zn}, \mathrm{Pb}, \mathrm{Th}$, $\mathrm{Cu}, \mathrm{Co}, \mathrm{As})$ inthe vicinity of the area varied location to location; however, soil-4,soil-6,soil-9, soil-11, soil-13, soil14,soil-15,soil-16,soil-17, soil-19 of the study area are slightly contaminated by $\mathrm{Mg}, \mathrm{Zn}$ and $\mathrm{Pb}$, whereas other sampling points are either uncontaminated or moderately contaminated by $\mathrm{Mg}, \mathrm{Zn}$ and $\mathrm{Pb}$, and uncontaminated by all other elements studied.The $\mathrm{EF}$ values for $\mathrm{K}, \mathrm{Fe}, \mathrm{Zr}, \mathrm{Rb}, \mathrm{Sr}, \mathrm{Cu}, \mathrm{Co}, \mathrm{Pb}, \mathrm{Zn}, \mathrm{Y}$, and $\mathrm{Ca}$ showed that these metals were derived mainly fromnatural processes or geogenic sources and were related to the exposure of the Earth's crustmaterial, with no evidence of the tailings dump impacts. However, Ti indicated moderateenrichment with maximum EF values of 2 and 5respectively. Zinc showed very high contamination in soil and made contribution to

373 contamination of the soilexpressed by contamination factor, $\mathrm{CF}(\mathrm{CF}>4)$. Only sampling point Soil-19 is highly

374 contaminated by $\mathrm{Zn}$, considerably contaminated by $\mathrm{Mg}$ and $\mathrm{Pb}$, and moderately contaminated by $\mathrm{Fe}, \mathrm{Co}, \mathrm{Cu}, \mathrm{Rb}, \mathrm{Sr}$,

$375 \mathrm{As}, \mathrm{Rb}, \mathrm{Y}$, and Th. Besides, all the sampling points are contaminated, though low in concentration, by $\mathrm{Al}, \mathrm{K}, \mathrm{Co}, \mathrm{Ca}$ 376 and Sr. The degree of contamination at different points reveals that sampling point soil-16 around Jamuna Fertilizer

377 is very highly contaminated.Mean Ecological Risk Assessment value (RI) followed a sequence of $378 \mathrm{~Pb}>\mathrm{As}>\mathrm{Co}>\mathrm{Cu}>\mathrm{Zn}$. The calculated RI values indicate moderate ecological risk by $\mathrm{Pb}, \mathrm{As}$ and low ecological risk by $379 \mathrm{Co}, \mathrm{Cu} \& \mathrm{Zn}$ in the particular area.Nemerow pollution index indicated $10 \%$ sampling sites have low pollution, 380 whereas $20 \%$ are severe and $70 \%$ are moderately polluted. Human health risk assessment showed that noncarcinogenic risk by the element $\mathrm{Cu}, \mathrm{Zn}, \mathrm{Pb}$ and $\mathrm{As}$ in the fertilizer area soil is negligible for both population groups

382 and carcinogenic risk assessment for Pb\&As for both population groups (adult and children) lies within Grade II 383 group $\left(10^{-5}\right.$ to $\left.10^{-6}\right)$ and are considered to be at no risk.

384 Multivariate statistical analysisrevealed source of all the elements are mostly geogenicaly and affected by 385 agricultural practice, liming, wastes from cement factories and use of excessive fertilizers and dust particle 386 etc.Vehicle- break and tire- wear are also the source of some elements $(\mathrm{Pb}, \mathrm{Zn})$ in the soil of that particular area.

\section{Acknowledgement}


389 The authors would like to express their thanks and gratitude to all the staff members of Atmospheric and

390 Environmental Chemistry laboratory, Atomic Energy Centre, Dhaka to carry out this research work.

\section{$391 \quad$ Ethical Approval}

392 All the authors of this research work gave their consent to publish the article.

393 Consent to Participate

394 N/A

395 Consent to Publish

396 N/A

397 Authors Contribution

398 ShirinAkter: samplecollection and analysis, data calculation; MehediHasan, SaifulIslamTushar: statistical analysis

399 of data, Mottalib Hossain Sarkar, Khan Mohammad Mamun, Mohammad JamiulKabir: sample preparation and

400 analysis, Mohammad Obidur Rahman, Mohammad Safiur Rahman, Mohammad JoynalAbedin, and BilkisAra

401 Begum :Writing, YeasminNahar Jolly: writing, editing and final approval of the manuscript.

$402 \quad$ Funding

403 The present work didn't receive any fund from any government or non-government organization.

404 Competing of Interests

405 The authors declare that they have no known competing financial interests or personal relationships that could have 406 appeared to influence the work reported in this research paper.

407 Availability of data and materials

408 N/A

409 References

410 Abrahim, GMSand Parker, RJ (2008) Assessment of Heavy Metal Enrichment Factors and the Degree of 411 Contamination in Marine Sediments from Tamaki Estuary, Auckland, New Zealand. Environmental 412 Monitoring and Assessment, 136, 227-238. http://dx.doi.org/10.1007/s10661-007-9678-2

413Ahmad, JU \& Goni, M A (2010) Heavy metal contamination in water, soil, and vegetables of the industrial areas in 414 Dhaka, Bangladesh. Environ Monit Asses, 166(1-4), 347-357.166:347-357.DOI 10.1007/s10661-0091006-6 
Abdullah, Al,Zabir, M, Wahid, U,Zaman, MD, Zakir, H,Nizam Uddin, M, Islam, MS(2016) Spatial Dissemination of Some Heavy Metals in Soil Adjacent to Bhaluka Industrial Area,Mymensingh, Bangladesh. 2(6),38-47 Doi: 10.11648/j.ajasr.20160206.12

Akter,Shirin, Islam, A, Rahman, MO, Mamun, KM, Kabir, J, Rahman, MS, Begum, BA, Abedin, MJ, Tushar, SIand Jolly, YN (2019) Toxic Elements Accumulation in Vegetables from Soil Collected from the Vicinity of a Fertilizer Factory and Possible Health Risk. Open Acess Journal of Biomedical Engineering and Biosciences Engineering and Biosciences.DOI: 10.32474/OAJBEB.2019.03.000159

Aucejo, A, Ferrer, J, Gabaldo, N, Marzal, P and Seco, A (1997) Diagnosis of Boron, Fluorine, Lead, Nickel and Zinc toxicity in cttrus plant ations in Villarreal, Spain. Water, Air, and Soil Pollution 94,349-360

Bhuiyan, MAH, Parvez, L, Islam, MA,Dampare, SB, Suzuki, S (2010) Heavy metal pollution of coal mineaffected agricultural soils in the northern part of Bangladesh. Journal of hazardous materials, 179 (13),1065-1077

Chen, YDA, Jackson, A and Harvey, HH (1992) A comparison of von bertalanffy and polynomial function in modeling fish growth data.Can J Fish AqualSci,49, 1228-1235

Dickinson, WW, Dunbar,GB and McLeod, H(1996) Heavy metal history from cores in Wellington Harbour, New Zealand.Environ Geol, 27, 59 -69

Eriyamremu, GE, Asagba, SO,Akpoborie, A and Ojeaburu, SI (2005) Evaluation of lead and cadmium levels in some commonly consumed vegetables in the Niger-Delta oil area of NigeriaBulletin of Environmental Contamination and Toxicology, 75, 278-283

Ferreira-Baptista, L and De Miguel, E (2005) Geochemistry and risk assessment of street dust in Luanda, Angola:a tropical urban environment . Atmospheric environment, 39(25), 4501-4512

Facchinelli, A, ElisaSacchi, Mallen, L (2001) Multivariate Statistical and GIS-based Approach to Identify Metal Sources in Soils. Environmental Pollution, 114(3), 313-24 DOI: 10.1016/S0269-7491(00)00243-8

Fusion, J (1999) What Is Soil Pollution?

Gu, Y G, Gao, Y P \& Lin, Q (2016) Contamination, bio-accessibility and human health risk of heavy metals in exposed-lawn soils from 28 urban parks in southern China's largest city, Guangzhou. Applied geochemistry, 67, 52-58 
Hakanson, L (1980) An ecological risk index for aquatic pollution control, a sediment ecological approach.Water Res 14, $975-1001$

Hamaker, J W and Thompson, JM (1972) Adsorption. In: Organic Chemicals in the Soil Environment (Goring, CandHamaker, J, Eds), Marcel Dekker, New York, 49-143

Horning, H, Krom,MD and Cohen, Y (1989) Trace metal Distribution in sediments and Benthic Fauna of Haifa Bay,

Israel, Estuarine,Coastal and Shelf Science, 29, 43-56

Ihedioha, JN, Ukoha, P O and Ekere, NR(2017) Ecological and human health risk assessment of heavy metal contamination in soil of a municipal solid waste dump in Uyo, Nigeria. Environmental geochemistry and health, 39(3), 497-515

Islam, A and Jolly, YN (2007) Heavy metals in water and fishes of the tannery affected vicinity of the River Buriganga. Journal of Bangladesh Academy of Sciences, 31( 2) ,163-171

Jolly, Y N, Islam, A, Mustafa,A I (2012) Impact of Dyeing Industry Effluent on Soil and Crop. Universal Journal of Environmental Research and Technology, 2(6), 560-568

Jolly, Y N, Akter,S ,Kabir, J , Islam, A (2013) Health risk assessment of heavy metals via dietary intake of vegetables collected from an area selected for introducing a Nuclear Power Plant. Research journal of physical and Sciences ,2 (4), 43-51

Jolly, Y N, Shohel, R, Akter, S , Kabir, J, Rahman, MS , Rahman, M M and Sultana, MS (2018) Appraisal of metal pollution in the aquatic environment of Shitalakhya river, Bangladesh and its ecological risk assessment.Journal of Nature Science and Sustainable Technology ,12 (4), 289-313

Kodom, K, Preko, K and Boamah, D (2012) X-ray Fluorescence (XRF) Analysis of Soil Heavy Metal Pollution from an Industrial Area in Kumasi, Ghana. Soil and Sediment Contamination, 21, 1006- 1021, DOI: $10.1080 / 15320383.2012 .71207$

Li, Z, Ma,Z, Van der Kuijp, TJ , Yuan, Z and Huang, L(2014) A review of soil heavy metal pollution from mines in China: pollution and health risk assessment. Science of the total environment, 468, 843-853

Martin, JM, Meybeck, M(1979) Elemental mass balance of materials carried by major world rivers. MarChem 1979; 7, 173-206

Müller, G,Schwermetalle in den sedimenten des RheinseVeranderungenseitt (1971) Umschau 1979, 778- 783 
470 Muchuweti, M, Birkett, JW, Chinyanga, E, Zvauya, R, Scrimshaw, MD and Lester, J N ( 2006) Heavy metal

471

472

473

474

475

476

477

478

479

480

481

482

483

484

485 content of vegetables irrigated with mixture of wastewater and sewage sludge in Zimbabwe: Implication for human health. Agric Eco and Environ ,112, 41-48

Ratul, AK, Hassan, M, Uddin, MK, Sultana, MS, Akbor, MA and Ahsan, MA (2018)Potential health risk of heavymetals accumulation in vegetables irrigated with polluted river water.International Food Research Journal ,25(1), 329-338 , Journal homepage: http://www.ifrj.upm.edu.m

Reimann, C andCaritat, P (1998) Chemical Elements in the Environment. Factsheets for the Geochemist and Environmental Scientist. ix+398 pp. Berlin, Heidelberg, New York, London, Paris, Tokyo, Hong Kong: Springer-Verlag. Geological Magazine 137(5):593-598 DOI:10.1017/S0016756800264613

Singh, A, Sharma, RK, Agrawal, M and Marshall, FM (2010) Risk assessment of heavy metal toxicity through contaminated vegetables from waste water irrigated area of Varanasi, India.Tropical Ecology,51(2S), 375387

Senesi, GS, Baldassarre, G, Senesi, N and Radina, B (1999) Trace element inputs by anthropogenic activities and implications for human health. Chemosphere,39, 343-377

US EPA (2001) US Environmental Protection Agency. Supplemental Guidance for Developing Soil Screening Levelsfor Superfund Sites. OSWER 9355.4-24. Office of Solid Waste and Emergency Response 
Figures

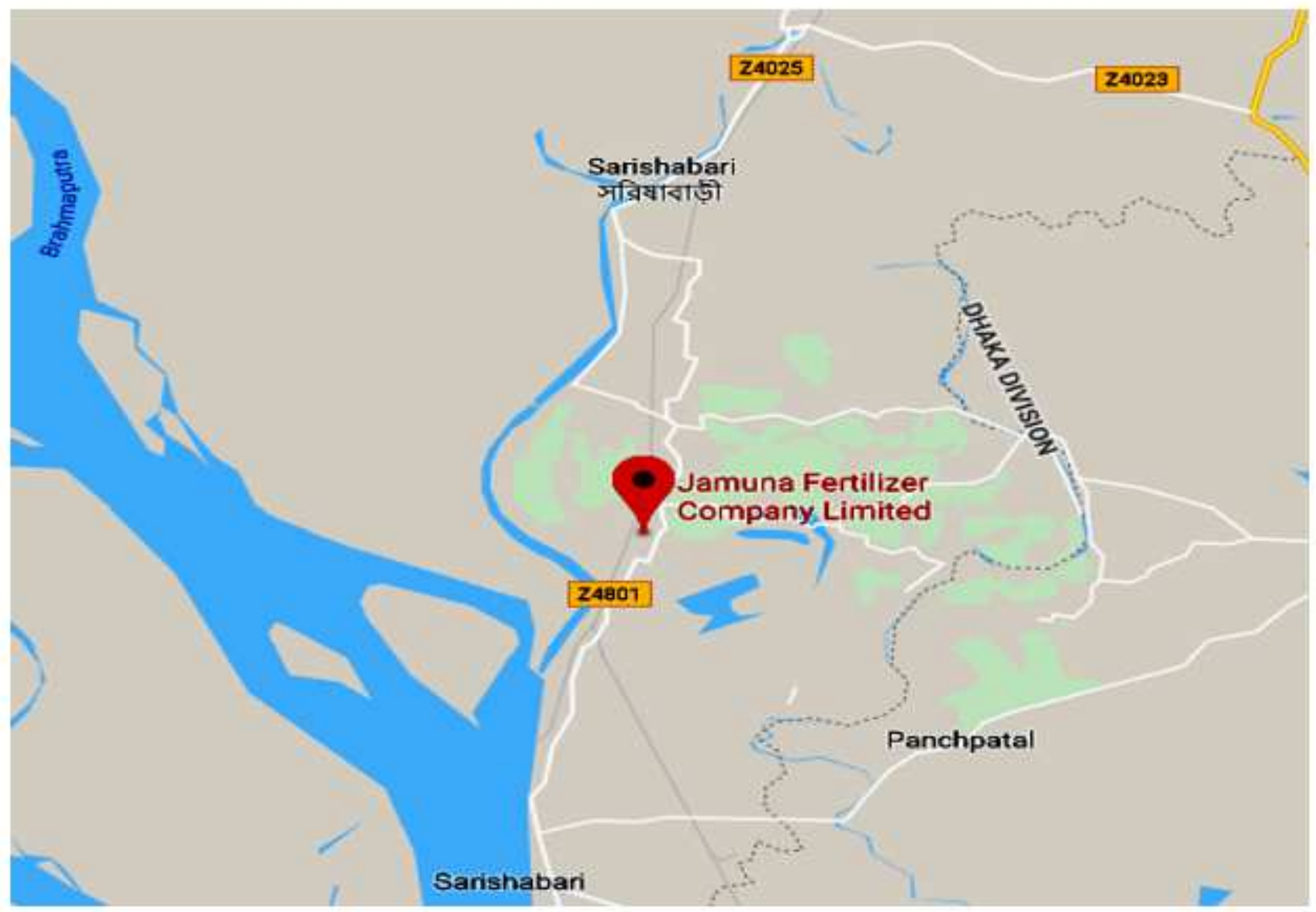

\section{Figure 1}

Jamuna fertilizer area Note: The designations employed and the presentation of the material on this map do not imply the expression of any opinion whatsoever on the part of Research Square concerning the legal status of any country, territory, city or area or of its authorities, or concerning the delimitation of its frontiers or boundaries. This map has been provided by the authors. 


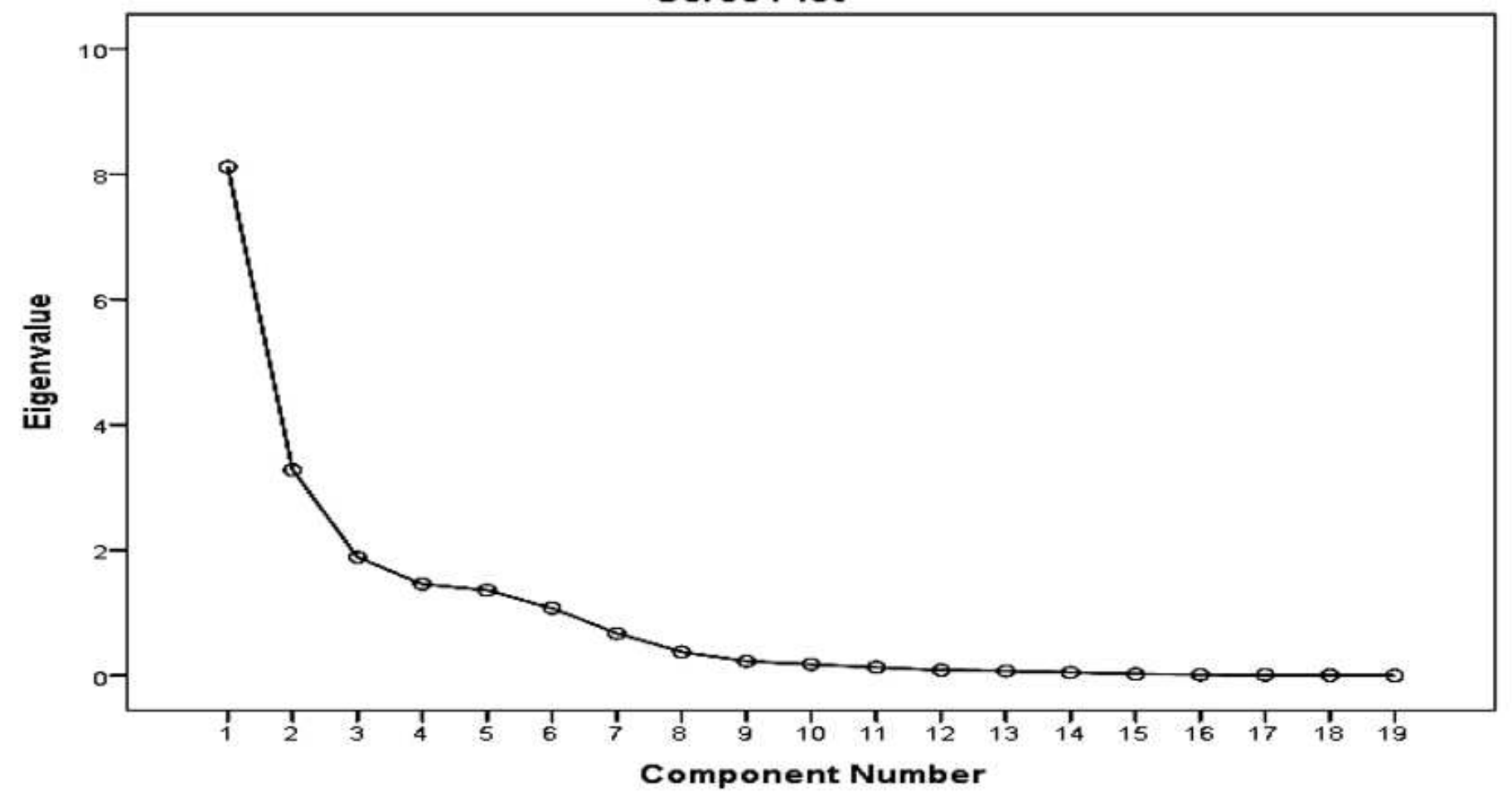

Figure 2

Scree plot of the characteristic roots 


\section{Component Plot in Rotated Space}

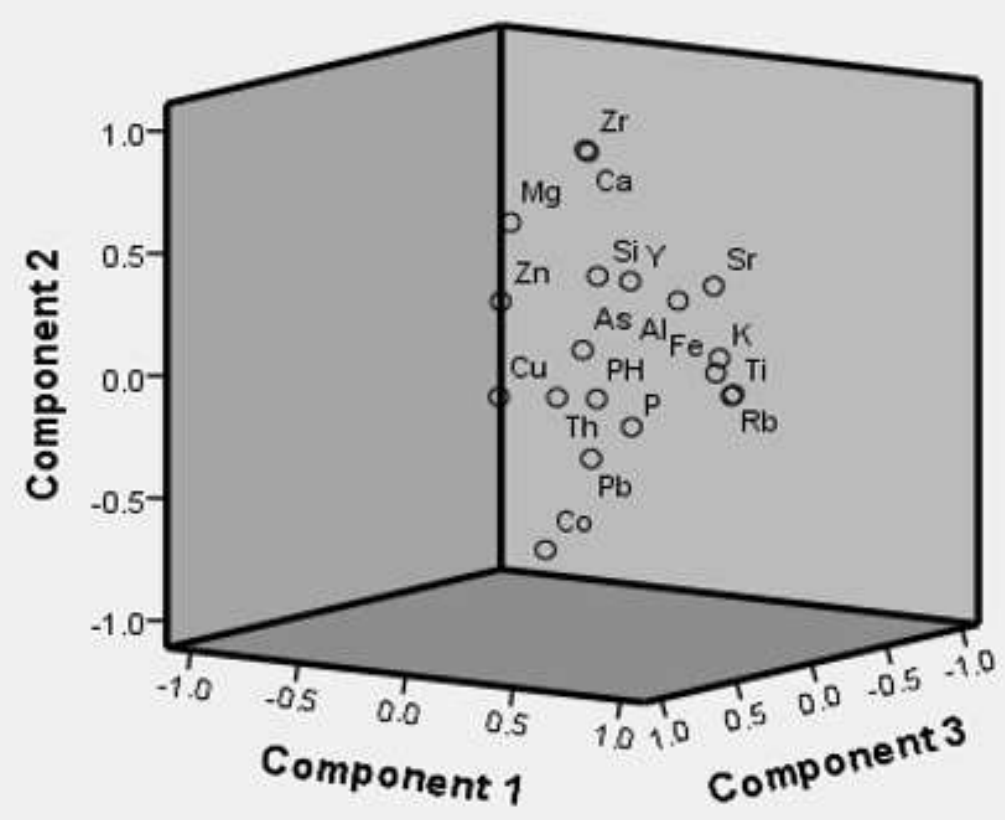

Figure 3

Component plot in rotated space of Principal component analysis. 


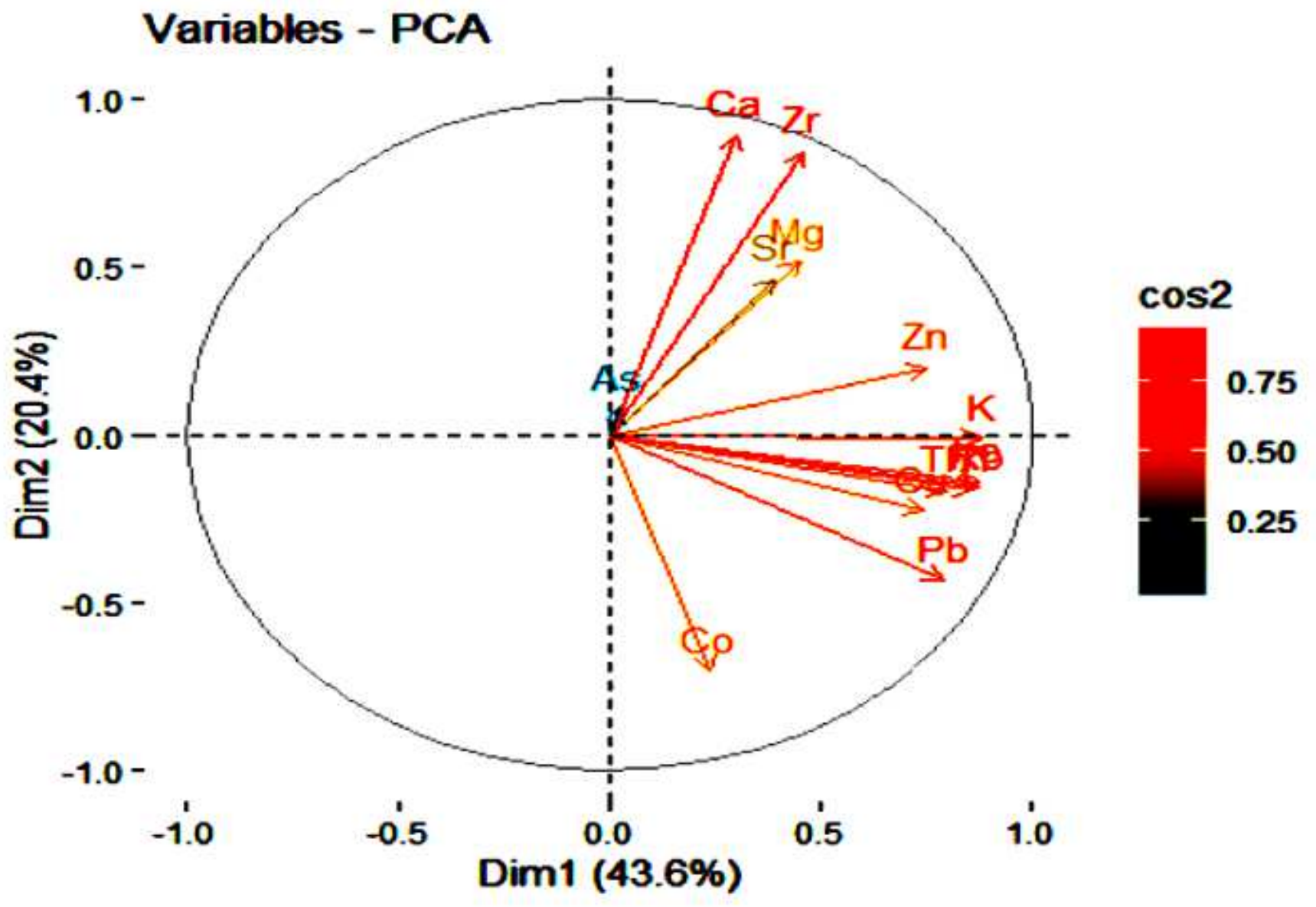

Figure 4

PCA correlation circle for the studied elements 


\section{Igeo}

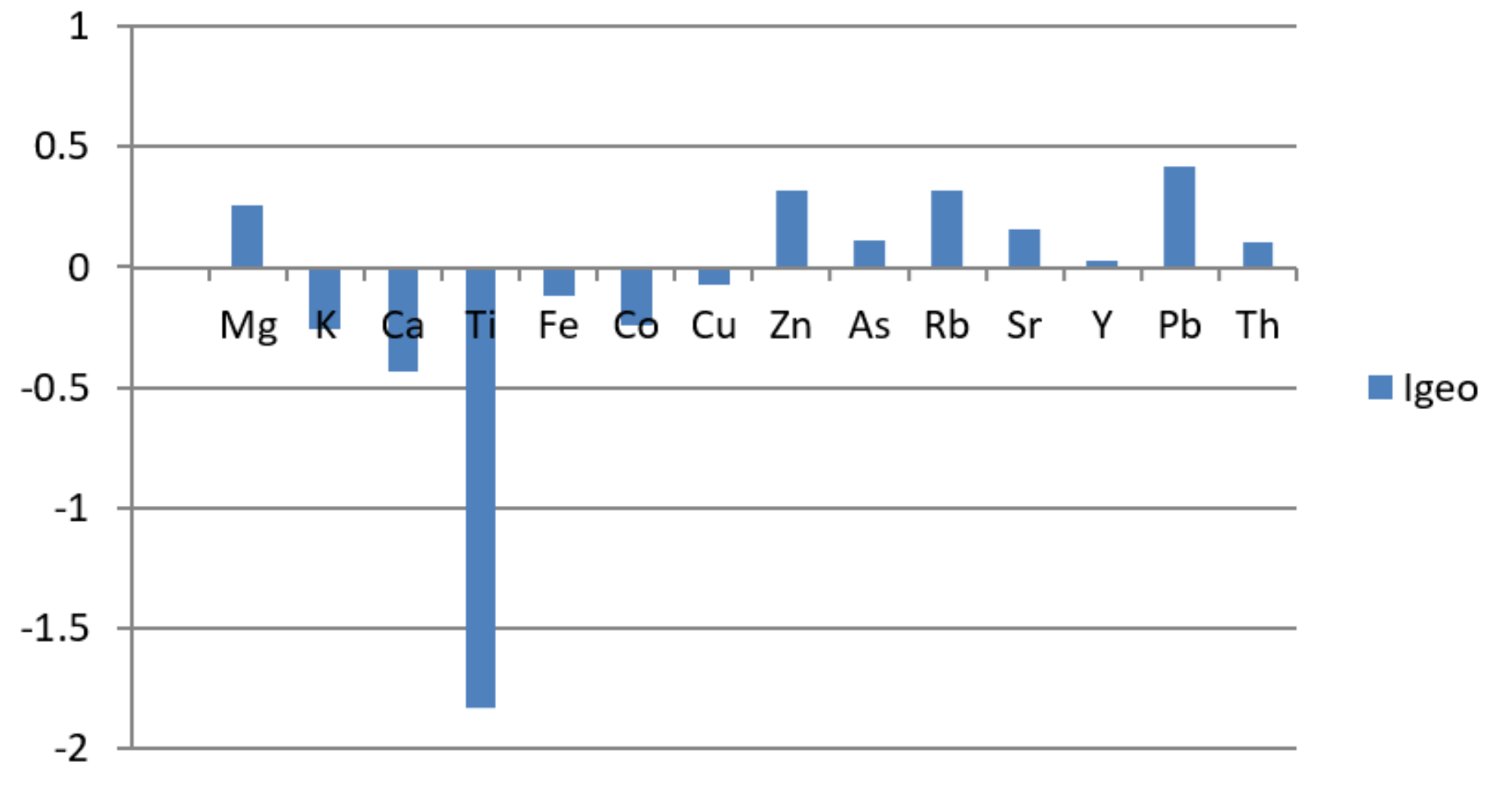

Figure 5

The degree of metal pollution of soil samples according to the Geo-accumulation index (Igeo). 


\section{Enrichment Factor values}

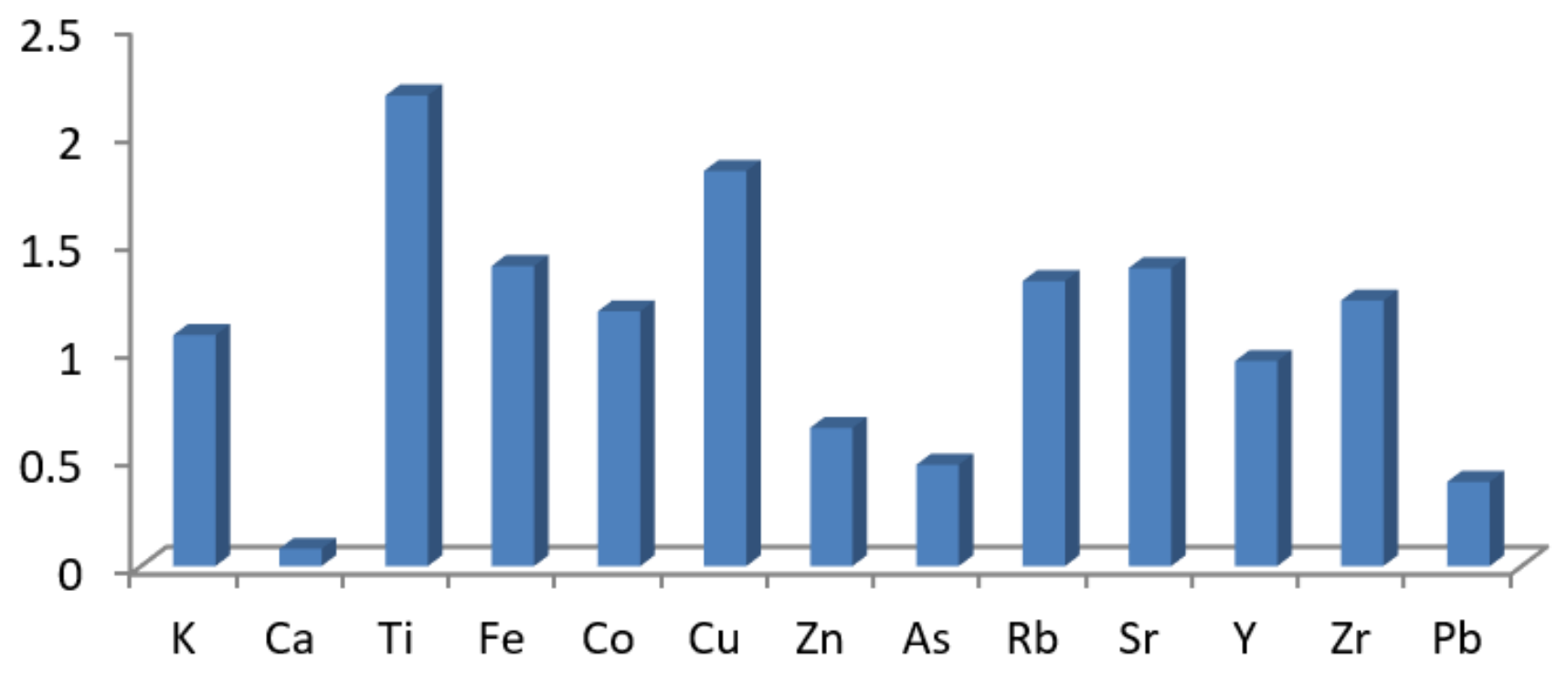

Figure 6

Enrichment Factor value (EF) for Soil Samples of Jamuna fertilizer area
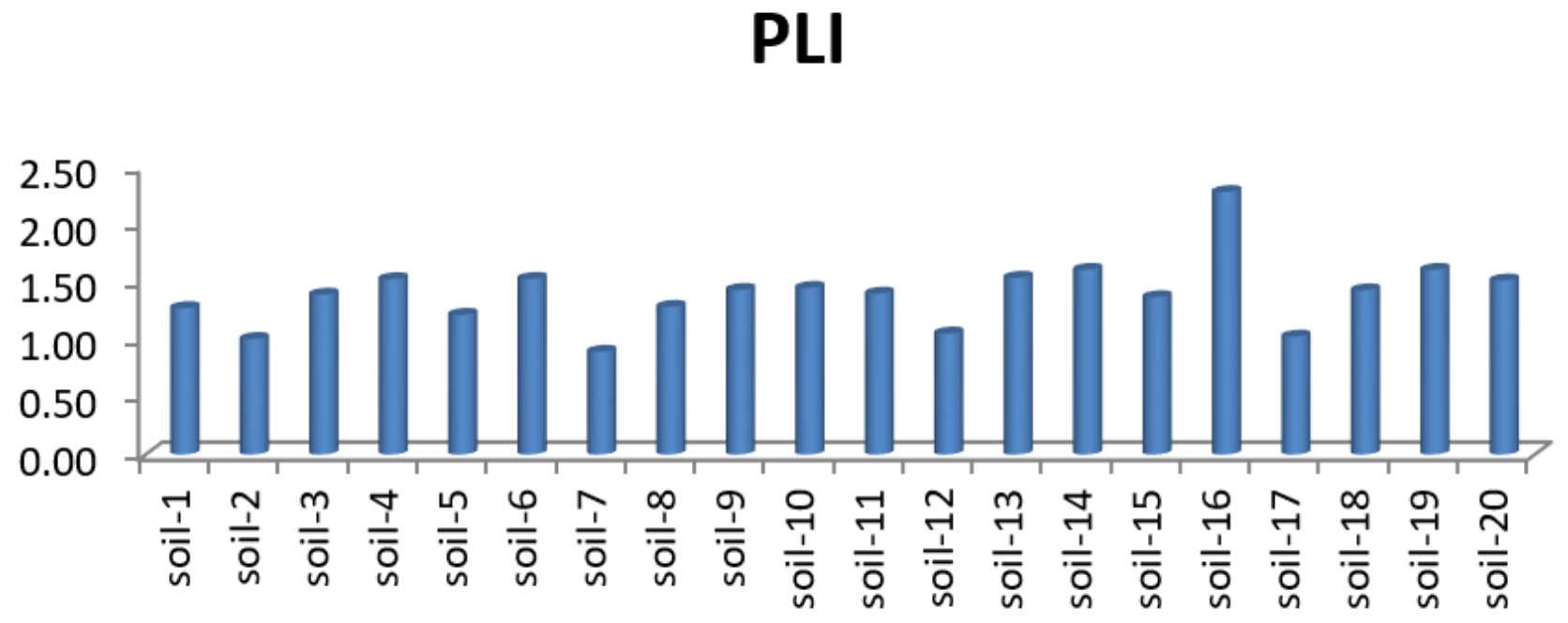

Figure 7

Pollution Load Index (PLI) of soil of Jamuna fertilizer area 